\title{
MBO Stages en de migratieachtergrond van studenten
}

Citation for published version (APA):

Bles, P., \& Meng, C. (2018). MBO Stages en de migratieachtergrond van studenten. ROA. ROA Fact Sheets No. 017 https://doi.org/10.26481/umarof.2018017

Document status and date:

Published: 01/01/2018

DOI:

10.26481/umarof.2018017

Document Version:

Publisher's PDF, also known as Version of record

\section{Please check the document version of this publication:}

- A submitted manuscript is the version of the article upon submission and before peer-review. There can be important differences between the submitted version and the official published version of record.

People interested in the research are advised to contact the author for the final version of the publication, or visit the DOI to the publisher's website.

- The final author version and the galley proof are versions of the publication after peer review.

- The final published version features the final layout of the paper including the volume, issue and page numbers.

Link to publication

\footnotetext{
General rights rights.

- You may freely distribute the URL identifying the publication in the public portal. please follow below link for the End User Agreement:

www.umlib.nl/taverne-license

Take down policy

If you believe that this document breaches copyright please contact us at:

repository@maastrichtuniversity.nl

providing details and we will investigate your claim.
}

Copyright and moral rights for the publications made accessible in the public portal are retained by the authors and/or other copyright owners and it is a condition of accessing publications that users recognise and abide by the legal requirements associated with these

- Users may download and print one copy of any publication from the public portal for the purpose of private study or research.

- You may not further distribute the material or use it for any profit-making activity or commercial gain

If the publication is distributed under the terms of Article $25 \mathrm{fa}$ of the Dutch Copyright Act, indicated by the "Taverne" license above, 
Maastricht University $\$$ ROA

MBO Stages en de migratieachtergrond van studenten

\section{ROA Fact Sheet}

ROA-F-2018/17

Researchcentrum voor Onderwijs en Arbeidsmarkt | ROA Research Centre For Education and the Labour Market / ROA 


\section{MBO Stages en de migratieachtergrond van studenten}

\section{Inleiding}

Jaarlijks worden in Nederland grootschalige onderzoeken verricht onder gediplomeerden, waaronder ook die van het middelbaar onderwijs (mbo)'. De gediplomeerden van het mbo wordt daarbij ongeveer anderhalf jaar na het behalen van het diploma gevraagd om terug te kijken op de gevolgde mbo-opleiding alsmede om informatie te verstrekken over de transitie tussen gevolgde mbo-opleiding en arbeidsmarkt/vervolgopleiding. Deze factsheet presenteert resultaten uit de onderzoeken die in de jaren 2014 (gediplomeerden van het schooljaar 2012-2013) tot en met 2017 (gediplomeerden van het schooljaar 2015-2016) hebben plaatsgevonden.

We presenteren de antwoorden over de ervaringen tijdens de mbo-opleiding wat het zoeken en vinden van een stage- of beroepspraktijkvormingsplaats (bpv) betreft. Meer specifiek draait het om de vraag hoe snel mbo'ers een stage- of bpv-plek vinden en in hoeverre hierin verschillen zijn tussen jongeren zonder een migratieachtergrond, jongeren met een westerse migratieachtergrond en jongeren met een niet-westerse migratieachtergrond.

Het is belangrijk om voorafgaand een tweetal opmerkingen te plaatsen.

Ten eerste, de onderzochte vragen hebben voor jongeren die een mbo-bbl opleiding gevolgd hebben betrekking op het vinden van een bpv-plaats aan het begin van de opleiding. Tijdens de gehele opleiding is deze groep gemiddeld zo'n 4 dagen per week werkzaam in deze bpv-plaats. Voor de jongeren die een mbo-bol opleiding hebben gevolgd hebben de vragen betrekking op het vinden van een plaats tijdens de opleiding waarin ze voor een bepaalde tijdsperiode een stage hebben gevolgd.

Ten tweede, de groep die de vragenlijst heeft ingevuld, is de groep studenten die de mbo-opleiding succesvol heeft afgerond. Jongeren die geen stage-/bpv-plaats konden vinden en daarom de opleiding niet konden afronden dan wel de opleiding in het geval van het mbo-bbl niet gestart zijn en het onderwijs hebben

1 De BVE-Monitor wordt door het CBS in samenwerking met het Researchcentrum voor Onderwijs en Arbeidsmarkt (ROA) uitgevoerd. verlaten, zijn niet bevraagd. In hoeverre dit de gepresenteerde uitkomsten beïnvloed is niet te achterhalen.

In de paragrafen 2-4 worden eerst enkele beschrijvende gegevens gepresenteerd over de mate waarin men tijdens de opleiding moeite ondervond om een stageplaats te krijgen, hoe vaak men diende te solliciteren, in hoeverre men tevreden was met de begeleiding vanuit de stageplaats en vanuit de school, en ten slotte wordt een indicatie gegevens van de mate waarin in de stage alle aspecten van het beroep aan bod gekomen zijn. We kijken daarbij naar eventuele veranderingen in de periode 2014-2017, en presenteren mogelijke verschillen tussen de twee leerwegen in het mbo (bol en bbl), de vier mbo-niveaus en de te onderscheiden opleidingssectoren.

In het tweede gedeelte van de factsheet (Paragraaf 5) wordt getracht de gevonden verschillen tussen jongeren zonder migratieachtergrond, met westerse migratieachtergrond en met niet-westerse migratieachtergrond in het aantal keer dat men heeft moeten solliciteren nader te verklaren.

\section{Het vinden van een stage-/bpv-plaats}

In de afgelopen vier metingen (2014-2017) van het schoolverlatersonderzoek zien we dat ongeveer $85 \%$ van de respondenten aangeeft 1 tot en met 3 keer gesolliciteerd te hebben op een stage-/bpv-plaats tijdens hun mbo-opleiding. Voor de groep jongeren zonder migratieachtergrond is dit percentage ongeveer $87 \%$, terwijl deze voor de groep jongeren met een westerse migratieachtergrond $83 \%$ is en voor jongeren met een niet-westerse migratieachtergrond $72 \%$. Figuur 1 laat zien dat, wanneer we deze getallen uitsplitsen naar jaar, het verschil tussen jongeren met een niet-westerse en zonder migratieachtergrond in het percentage leerlingen dat 1 tot en met 3 keer dient te solliciteren naar een stageplaats is afgenomen van 17\%-punt (2014 en 2015) naar 12\%-punt (2017).

Kijken we voor het meetjaar 2017 nader naar de groep die maximaal 3 keer diende te solliciteren, is zichtbaar dat onder de jongeren zonder migratieachtergrond $68 \%$ de stage-/bpv-plaats zelfs met slechts 1 sollicitatie vond, terwijl dit cijfer voor jongeren met een niet-westerse migratieachtergrond ongeveer op $48 \%$ ligt. Ook bij de groep die minimaal 4 keer diende te solliciteren, laten 


\section{Fact Sheet}

ROA-F-2018/17

de onderliggende cijfers nadere verschillen zijn. Zo geeft in meeting 2017 van de jongeren met een niet-westerse migratieachtergrond $13 \%$ aan dat ze minimaal 7 keer dienden te solliciteren terwijl dit bij de jongeren zonder migratieachtergrond $5 \%$ is.

In hoeverre hangt het objectieve gegeven van het aantal keer dat men voor een stageplaats solliciteerde samen met een meer subjectieve meting van het ondervinden van problemen tijdens het vinden van een stage-/ bpv-plek? Ook hier zijn duidelijke verschillen zichtbaar. Over de gehele onderzochte periode geeft $25 \%$ van de jongeren met een niet-westerse achtergrond aan problemen te hebben ondervonden. Onder de groep jongeren met een westerse migratieachtergrond is dit $20 \%$ en van de jongeren zonder migratieachtergrond had 'slechts' $15 \%$ problemen ondervonden. Vooral tussen 2015 en 2017 daalt, in lijn met de verbeterede arbeidsmarktsituatie, voor alle groepen het aandeel dat moeite ondervond. In 2017 waren deze percentages respectievelijk $23 \%, 18 \%$ en $14 \%$.

\section{FIGUUR 1.}

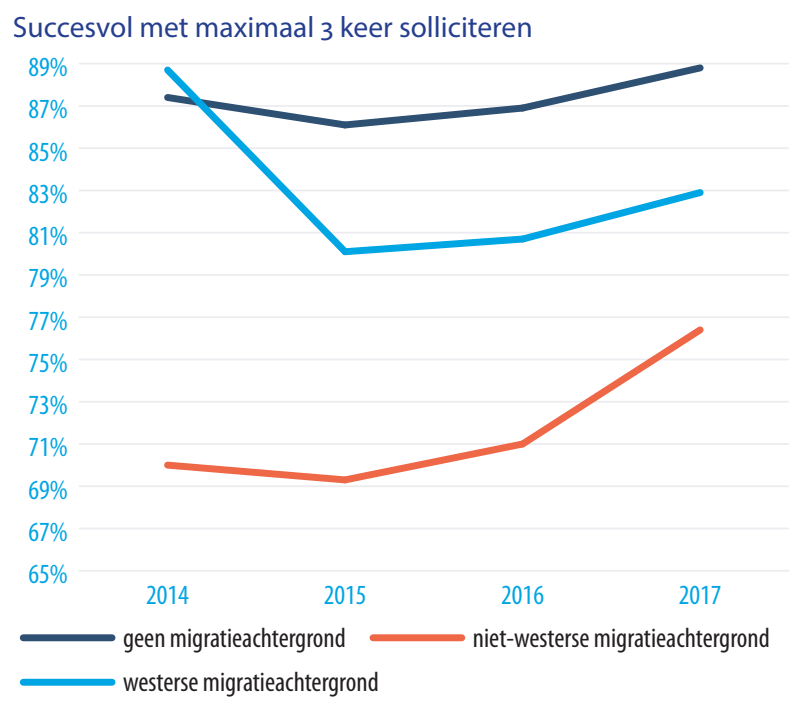

De data laten verschillen in patronen zien tussen de mbo beroepsbegeleidende leerweg (bbl) en de beroepsopleidende leerweg $(\mathrm{bol})^{2}$. Het percentage gediplomeerden dat 1 tot en 3 keer diende te solliciteren is bij bbl-oplei-

2 Het is belangrijk om nogmaals op te merken dat de vragen in het mbo-bbl betrekking hebben op het vinden van een bpvplaats aan het begin van de opleiding en voor met mbo-bol op het vinden van een stageplek tijdens de opleiding. dingen ongeveer 91\% en bij bol-opleidingen ongeveer $82 \%$. Dit verschil is voor jongeren met een niet-westerse migratieachtergrond ongeveer even groot $(80 \%$ om $71 \%$ ) en voor jongeren zonder migratieachtergrond kleiner (92\% om 85\%). Het verschil tussen jongeren met een niet-westerse migratieachtergrond en jongeren zonder migratieachtergrond is dus iets groter is in het mbo-bol dan het mbo-bbl.

Het verschil tussen jongeren met en zonder nietwesterse migratieachtergrond in percentage van jongeren dat aangeeft problemen te hebben ondervonden verschilt enigzins tussen bbl (13\% van de jongeren met niet-westerse migratieachtergrond om $8 \%$ van de jongeren zonder migratieachtergrond) en bol ( $27 \%$ om 19\%). Het algehele niveau van ondervinden van problemen ligt bij bbl lager dan bij bol.

Als we naar verschillen tussen de mbo-niveaus kijken zien we dat de verschillen tussen de verschillende groepen met en zonder migratieachtergrond groter zijn dan tussen de niveaus. Het percentage gediplomeerden dat met 1 tot en met 3 keer solliciteren een plek vond, varieert tussen 70\% (mbo-niveau 4) en 78\% (mbo-niveau 1) voor degenen met een niet-westerse migratieachtergrond en voor degenen zonder migratieachtergrond tussen 85\% (mbo-niveau 1) en 89\% (mbo-niveau 3). Ditzelfde patroon zien we ook als we kijken naar het percentage leerlingen dat problemen heeft ondervonden tijdens het solliciteren: het percentage met problemen varieert onder de groep met niet-westerse migratieachtergrond tussen $24 \%$ op mbo-niveau 2 en $26 \%$ op mbo-niveau 3 en voor jongeren zonder migratieachtergrond tussen $14 \%$ op mbo-niveau 3 en $17 \%$ op mbo-niveau 2.

Over de sectoren in het mbo heen zien we hetzelfde patroon: jongeren met een niet-westerse migratieachtergrond vinden het minst vaak een stage-/bpv-plek met maximaal 3 keer solliciteren (variërend van $65 \%$ in de sector economie tot $84 \%$ in de landbouwsector), gevolgd door de jongeren met een westerse-migratieachtergrond (variërend van $80 \%$ in de economische sector tot $91 \%$ in de sector gedrag \& maatschappij) en de jongeren zonder migratieachtergrond (variërend van $85 \%$ in de sector landbouw tot $91 \%$ in de sector gedrag \& maatschappij). Het verschil is het grootst in de sector economie, waar 20\%-punten verschil zit tussen jongeren 


\section{MBO Stages en de migratieachtergrond van studenten}

met niet-westerse migratieachtergrond en jongeren zonder migratieachtergrond. In de sectoren techniek en gedrag \& maatschappij ligt het verschil bij 12-13\% punt en in de sector gezondheidszorg bij $7 \%$ Het kleinst is dit in de sector landbouw³

\section{Aspecten van beroep}

We zagen in de vorige alinea over het algemeen een relatief duidelijk verschil tussen jongeren met een niet-westerse migratieachtergrond en jongeren zonder migratieachtergrond als het om het aantal keren sollicitaties ging dat men nodig had om een stage-/bpv-plek te vinden. Zou het moeilijker kunnen vinden van stage-/ bpv-plaats voor jongeren met een niet-westerse migratieachtergrond invloed hebben op het soort stage dat men uiteindelijk loopt? Een indicator die daarover iets kan zeggen is de vraag of de respondent vond dat alle aspecten van het beroep waarvoor men leert ook terugkwamen in de stage.

FIGUUR 2.

$\%$ dat vindt dat alle aspecten van het beroep aan bod kwamen $88 \%$

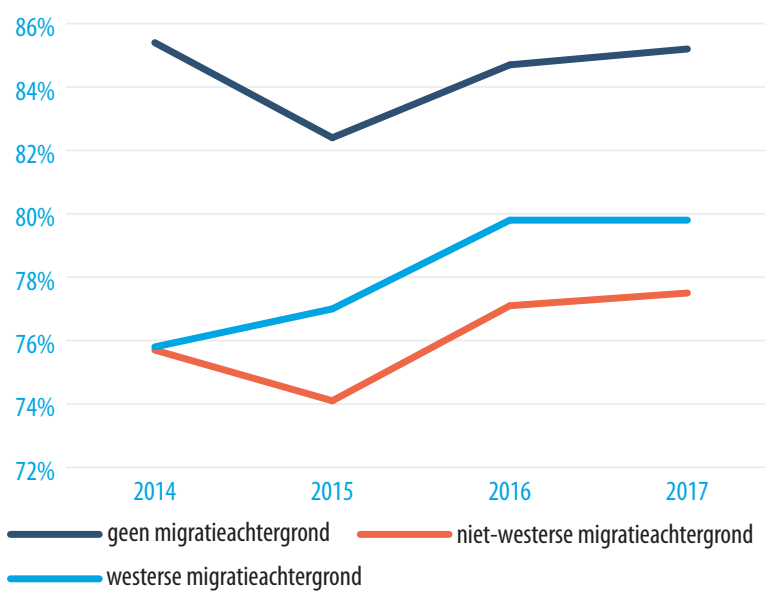

In Figuur 2 zien we dat het percentage leerlingen dat vindt dat alle aspecten van het beroep in de stage terugkomen vrij stabiel is binnen de groep jongeren met een niet-westerse migratieachtergrond en de groep zonder migratieachtergrond (schommelt tussen $74 \%$ en $77 \%$ en $83 \%$ en $85 \%$, respectievelijk). Wat ook duidelijk naar

3 Het aantal respondenten (vooral jongeren met een niet-westerse migratieachtergrond) in de steekproef met een opleiding in de sector landbouw is laag. De resultaten van deze sectoren dienen dan ook met voorzichtigheid te worden geïnterpreteerd. voren komt is dat tussen de groep jongeren met een niet-westerse migratieachtergrond en jongeren zonder migratieachtergrond het verschil ook weinig schommelingen laat zien (varieert van 9\% in 2014 en 8\% in 2016).

Voor zowel de leerweg als het niveau van de gevolgde mbo-opleiding geldt dat de verschillen tussen de jongeren met en zonder niet-westerse migratieachtergrond groter zijn dan de verschillen tussen de leerweg of het niveau.

Voor de sectoren geldt dat het verschil tussen jongeren met en zonder niet-westerse migratieachtergrond het grootst is voor de sector landbouw ${ }^{3}$ (17\%-punt), gevolgd door de sectoren economie en techniek (8\%-punt en 9\%-punt, respectievelijk) en het kleinst zijn voor de sectoren gezondheidszorg en gedrag \& maatschappij (6\%-punt en 5\%-punt, respectievelijk).

\section{De begeleiding van de stage/bpv}

Zijn er verschillen te observeren in de begeleiding van de stage/bpv vanuit zowel de mbo-instelling als de stage/-bpv-plaats tussen jongeren met en zonder (niet-) westerse migratieachtergrond? De begeleiding vanuit de school wordt door jongeren met een niet-westerse migratieachtergrond vaker als (zeer) tevreden omschreven (59\%) dan door jongeren zonder migratieachtergrond (52\%). In Figuur 3 is ook te zien dat jongeren zonder migratieachtergrond vaker de begeleiding vanuit school als (zeer) ontevreden karakteriseren (22\% om 17\%).

FIGUUR 3

Tevredenheid met begeleiding vanuit school

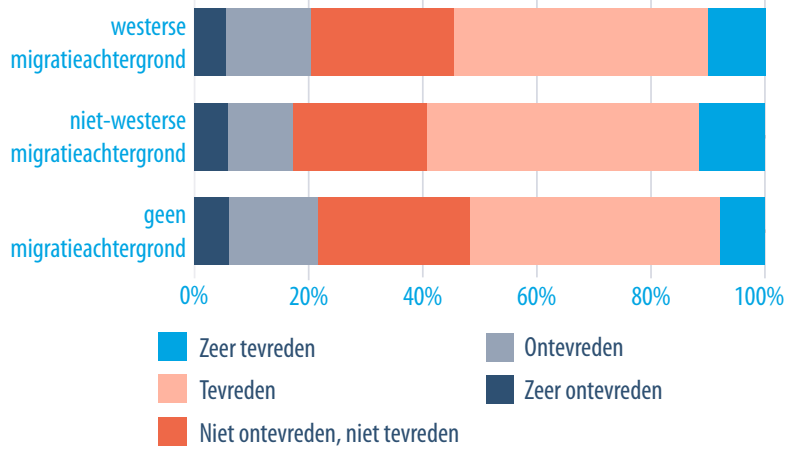

Kijken we naar de begeleiding vanuit de stage-/bpvplaats dan verandert het beeld. Jongeren met een nietwesterse migratieachtergrond zijn wat deze begeleiding 


\section{Fact Sheet}

ROA-F-2018/17

betreft minder vaak (zeer) tevreden dan jongeren zonder migratieachtergrond ( $69 \%$ om $73 \%$ ) en vaker (zeer) ontevreden (11\% om 9\%). Echter, de verschillen zijn marginaal.

\section{FIGUUR 4.}

Tevredenheid met begeleiding vanuit stage-/bpv-plaats

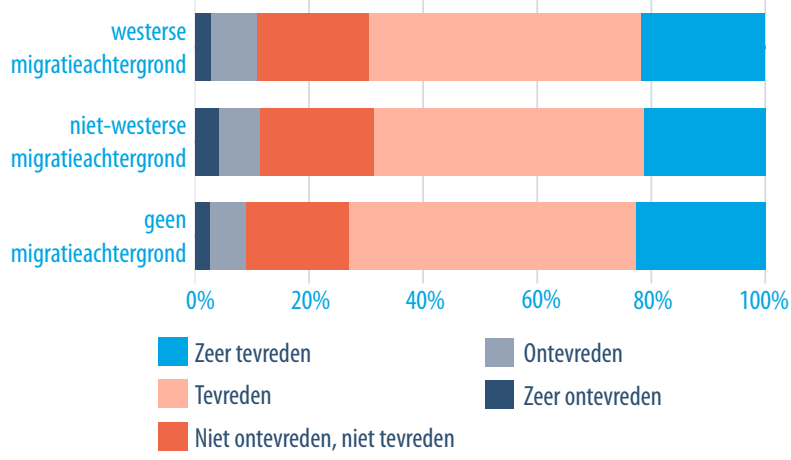

Het nader bekijken van de onderliggende data laat zien dat het hier gepresenteerde beeld ook geldt indien we de twee leerwegen (mbo-bol en mbo-bbl) of de vier mbo niveaus onderscheiden. Interessant is wel dat wat de niveus betreft de waardering voor de begeleiding vanuit de school bij jongeren die een mbo niveau 1 opleiding gevolgd hebben duidelijk hoger ligt. Van hen is zo'n 68\% (zeer) tevreden met de begeleiding vanuit de school terwijl op de andere drie niveaus het percentage tussen de $52 \%$ en $54 \%$ ligt. Ook als we kijken naar de verschillende opleidingsectoren, blijft het gepresenteerde beeld sterk overeind. Uitzondering is wederom de opleidingssector landbouw in welke door een matige tevredenheid onder de jongeren zonder migratieachtergrond wat de begeleiding vanuit de school betreft, het percetage dat (zeer) tevreden is, bij de groep jongeren met een niet-westerse migratieachtergrond zo'n 20\%-punt hoger ligt. Echter, we dienen de lezer er nog een keer op te attenderen dat het aantal respondenten met een niet-westerse migratieachtergrond in de opleidingssector landbouw relatief klein is.

\section{Nadere analyse: aantal sollicitaties}

Als we opnieuw kijken naar onze meest objectieve indicator van het vinden van een stage-/bpv-plek in het mbo is dat de vraag naar het aantal keer dat men heeft moeten solliciteren. We zagen dat in de groep jongeren zonder migratieachtergrond $87 \%$ met 1-3 sollicitaties een plek kon bemachtigen, terwijl dit in de groep jongeren met een westerse migratieachtergrond $83 \%$ is en in de groep jongeren met een niet-westerse migratieachtergrond 'slechts' $72 \%$ is. Anders geformuleerd: jongeren met een niet-westerse migratieachtergrond dienen vaker meer dan drie keer te solliciteren dan jongeren zonder een migratieachtergrond ( $28 \%$ om $13 \%$ ).

Binnen de groep jongeren met een niet-westerse migratieachtergrond is de verhouding tussen de groep die minimaal 4 keer diende te solliciteren en de groep die minder dan 4 keer diende te solliciteren 0,39 (28\%/72\%). Bij de groep jongeren zonder migratieachtergrond ligt de verhouding op 0,15 (13\%/87\%). De kans om minimaal 4 keer te moeten solliciteren is daarmee 2,6 keer zo groot voor de jongeren met een niet-westerse migratieachtergrond dan voor jongeren zonder migratieachtergrond. Deze verhouding wordt ook odds-ratio genoemd. De vraag is hoeveel daarvan eventueel verklaard kan worden door andere karakteristieken waarin de twee groepen jongeren van elkaar verschillen.

Om het verschil nader te verklaren zijn daarom een aantal multivariate analyses uitgevoerd:

- Model 1: Alleen dummy's voor migratieachtergrond

- Model 2: Model 1 plus dummy's voor provincie gevolgde mbo-opleiding

- Model 3: Model 2 plus jaar van meting

- Model 4: Model 3 plus geslacht een leeftijd

- Model 5: Model 4 plus gevolgde mbo-leerweg

- Model 6: Model 5 plus gevolgd opleidingsniveau

- Model 7: Model 6 plus gevolgde opleidingssector

- Model 8: Model 7 plus gemiddeld afstudeercijfer

Figuur 5.

Odds-ratio per geschat model.

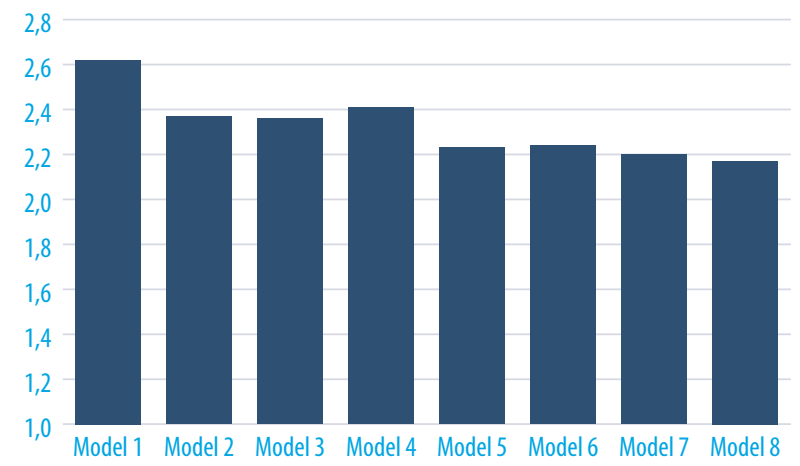

In Model 1 zien we de odds ratio van 2,6 terug. In Model 2 wordt de provincie waarin men de opleiding heeft 


\section{MBO Stages en de migratieachtergrond van studenten}

gevolgd toegevoegd aan de schatting van de odds ratio. Deze daalt naar 2,4. Zo'n 12\% van de oorspronkelijk ongelijkheid wordt daarmee verklaard door verschillen in de regionale spreiding van jongeren met een nietwesterse migratieachtergrond en jongeren zonder migratieachtergrond. Het toevoegen van het meetjaar (Model 3) en het geslacht en de leeftijd (Model 4) brengt geen verdere verklaring.

In Model 5 wordt de leerweg van de gevolgde mboopleiding meegenomen. We zien dat de odds ratio daalt naar 2,2. Dit betekent dat nog eens een 12\% van het initiële verschil wordt verklaard door de leerweg van de gekozen studie.

Het toevoegen van het niveau van de gevolgde mboopleiding in Model 6, de gevolgde opleidingssector in
Model 7 en het eindexamencijfer in Model 8 veranderd de odds ratio nauwelijks. Deze blijft ongeveer 2,2.

De uitkomst van de uitgevoerde modellen is dan ook dat 'slechts' zo'n 25\% van het initiële verschil door de in de data verder beschikbare karakteristieken verklaart kan worden. Ook naar controle voor regio, leerweg, opleidingsniveau, opleidingssector, geslacht, leeftijd en gemiddeld eindexamencijfer zien we dat jongeren met een niet-westerse migratieachtergrond in verhouding met jongeren zonder migratieachtergrond nog steeds een ongeveer 2,2 keer zo hoge kans hebben om minimaal 4 keer te moeten solliciteren om een stage-/bpvplaats in het mbo te bemachtigen. 


\section{Fact Sheet}

ROA-F-2018/17

Bijlage 1: Resultaten per meetjaar

\begin{tabular}{|c|c|c|c|c|c|}
\hline & & 2014 & 2015 & 2016 & 2017 \\
\hline & & $\%$ & $\%$ & $\%$ & $\%$ \\
\hline \multicolumn{6}{|l|}{ Westerse migratieachtergond } \\
\hline \multirow[t]{4}{*}{ Aantal keren solliciteren } & 1 tot 3 & 88 & 80 & 82 & 83 \\
\hline & 4 tot 6 & 5 & 9 & 9 & 9 \\
\hline & 7 tot 10 & 2 & 4 & 4 & 3 \\
\hline & meer dan 10 & 4 & 7 & 7 & 6 \\
\hline \multirow[t]{2}{*}{ Problemen ondervonden bij vinden van stage/bpv-plaats } & Ja & 20 & 19 & 21 & 18 \\
\hline & Nee & 80 & 81 & 79 & 82 \\
\hline \multirow[t]{2}{*}{ Alle aspecten van het beroep aan bod gekomen } & Ja & 76 & 77 & 80 & 80 \\
\hline & Nee & 24 & 23 & 20 & 20 \\
\hline \multirow[t]{3}{*}{ Tevredenheid: Begeleiding vanuit school } & (zeer) tevreden & n.a. & n.a & 21 & 20 \\
\hline & neutraal & n.a. & n.a & 25 & 25 \\
\hline & (zeer) ontevreden & n.a. & n.a & 54 & 55 \\
\hline \multirow[t]{3}{*}{ Tevredenheid: Begeleiding vanuit werk } & (zeer) tevreden & n.a. & n.a & 11 & 11 \\
\hline & neutraal & n.a. & n.a & 19 & 20 \\
\hline & (zeer) ontevreden & n.a. & n.a & 69 & 69 \\
\hline \multicolumn{6}{|l|}{ Niet-westerse migratieachtergond } \\
\hline \multirow[t]{4}{*}{ Aantal keren solliciteren } & 1 tot 3 & 70 & 69 & 71 & 76 \\
\hline & 4 tot 6 & 11 & 13 & 12 & 11 \\
\hline & 7 tot 10 & 5 & 5 & 6 & 4 \\
\hline & meer dan 10 & 15 & 12 & 11 & 9 \\
\hline \multirow[t]{2}{*}{ Problemen ondervonden bij vinden van stage/bpv-plaats } & $\mathrm{Ja}$ & 22 & 28 & 26 & 23 \\
\hline & Nee & 78 & 72 & 74 & 77 \\
\hline \multirow[t]{2}{*}{ Alle aspecten van het beroep aan bod gekomen } & Ja & 76 & 74 & 77 & 77 \\
\hline & Nee & 24 & 26 & 23 & 23 \\
\hline \multirow[t]{3}{*}{ Tevredenheid: Begeleiding vanuit school } & (zeer) tevreden & n.a. & n.a. & 17 & 18 \\
\hline & neutraal & n.a. & n.a. & 22 & 25 \\
\hline & (zeer) ontevreden & n.a. & n.a. & 60 & 58 \\
\hline \multirow[t]{3}{*}{ Tevredenheid: Begeleiding vanuit werk } & (zeer) tevreden & n.a. & n.a. & 11 & 12 \\
\hline & neutraal & n.a. & n.a. & 19 & 21 \\
\hline & (zeer) ontevreden & n.a. & n.a. & 70 & 68 \\
\hline \multicolumn{6}{|l|}{ Zonder migratieachtergrond } \\
\hline \multirow[t]{4}{*}{ Aantal keren solliciteren } & 1 tot 3 & 87 & 86 & 87 & 89 \\
\hline & 4 tot 6 & 6 & 7 & 7 & 6 \\
\hline & 7 tot 10 & 2 & 3 & 3 & 2 \\
\hline & meer dan 10 & 4 & 4 & 4 & 3 \\
\hline \multirow[t]{2}{*}{ Problemen ondervonden bij vinden van stage/bpv-plaats } & Ja & 14 & 17 & 16 & 14 \\
\hline & Nee & 86 & 83 & 84 & 86 \\
\hline \multirow[t]{2}{*}{ Alle aspecten van het beroep aan bod gekomen } & Ja & 85 & 82 & 85 & 85 \\
\hline & Nee & 15 & 18 & 15 & 15 \\
\hline \multirow[t]{3}{*}{ Tevredenheid: Begeleiding vanuit school } & (zeer) ontevreden & n.a. & n.a. & 22 & 22 \\
\hline & neutraal & n.a. & n.a. & 27 & 27 \\
\hline & (zeer) tevreden & n.a. & n.a. & 52 & 52 \\
\hline \multirow[t]{3}{*}{ Tevredenheid: Begeleiding vanuit werk } & (zeer) ontevreden & n.a. & n.a. & 9 & 9 \\
\hline & neutraal & n.a. & n.a. & 18 & 18 \\
\hline & (zeer) ontevreden & n.a. & n.a. & 74 & 73 \\
\hline
\end{tabular}




\section{MBO Stages en de migratieachtergrond van studenten}

Bijlage 2: Resultaten per leerweg

\begin{tabular}{|c|c|c|c|}
\hline & & MBO-BBL & MBO-BOL \\
\hline & & $\%$ & $\%$ \\
\hline \multicolumn{4}{|l|}{ Westerse migratieachtergond } \\
\hline \multirow[t]{4}{*}{ Aantal keren solliciteren } & 1 tot 3 & 90 & 80 \\
\hline & 4 tot 6 & 3 & 10 \\
\hline & 7 tot 10 & 2 & 4 \\
\hline & meer dan 10 & 5 & 6 \\
\hline \multirow[t]{2}{*}{ Problemen ondervonden bij vinden van stage/bpv-plaats } & Ja & 9 & 25 \\
\hline & Nee & 91 & 75 \\
\hline \multirow[t]{2}{*}{ Alle aspecten van het beroep aan bod gekomen } & $\mathrm{Ja}$ & 78 & 79 \\
\hline & Nee & 22 & 21 \\
\hline \multirow[t]{3}{*}{ Tevredenheid: Begeleiding vanuit school } & (zeer) ontevreden & 16 & 22 \\
\hline & neutraal & 25 & 25 \\
\hline & (zeer) tevreden & 59 & 53 \\
\hline \multirow[t]{3}{*}{ Tevredenheid: Begeleiding vanuit werk } & (zeer) ontevreden & 13 & 10 \\
\hline & neutraal & 23 & 19 \\
\hline & (zeer) tevreden & 64 & 71 \\
\hline \multicolumn{4}{|l|}{ Niet-westerse migratieachtergond } \\
\hline \multirow[t]{4}{*}{ Aantal keren solliciteren } & 1 tot 3 & 80 & 71 \\
\hline & 4 tot 6 & 7 & 13 \\
\hline & 7 tot 10 & 4 & 5 \\
\hline & meer dan 10 & 9 & 12 \\
\hline \multirow[t]{2}{*}{ Problemen ondervonden bij vinden van stage/bpv-plaats } & Ja & 13 & 27 \\
\hline & Nee & 87 & 73 \\
\hline \multirow[t]{2}{*}{ Alle aspecten van het beroep aan bod gekomen } & $\mathrm{Ja}$ & 78 & 76 \\
\hline & Nee & 22 & 24 \\
\hline \multirow[t]{3}{*}{ Tevredenheid: Begeleiding vanuit school } & (zeer) ontevreden & 14 & 18 \\
\hline & neutraal & 21 & 24 \\
\hline & (zeer) tevreden & 65 & 58 \\
\hline \multirow[t]{3}{*}{ Tevredenheid: Begeleiding vanuit werk } & (zeer) ontevreden & 12 & 11 \\
\hline & neutraal & 20 & 20 \\
\hline & (zeer) tevreden & 68 & 69 \\
\hline \multicolumn{4}{|l|}{ Zonder migratieachtergrond } \\
\hline \multirow[t]{4}{*}{ Aantal keren solliciteren } & 1 tot 3 & 92 & 85 \\
\hline & 4 tot 6 & 4 & 8 \\
\hline & 7 tot 10 & 1 & 3 \\
\hline & meer dan 10 & 3 & 4 \\
\hline \multirow[t]{2}{*}{ Problemen ondervonden bij vinden van stage/bpv-plaats } & $\mathrm{Ja}$ & 8 & 19 \\
\hline & Nee & 92 & 81 \\
\hline \multirow[t]{2}{*}{ Alle aspecten van het beroep aan bod gekomen } & Ja & 84 & 85 \\
\hline & Nee & 16 & 15 \\
\hline \multirow[t]{3}{*}{ Tevredenheid: Begeleiding vanuit school } & (zeer) ontevreden & 18 & 23 \\
\hline & neutraal & 28 & 26 \\
\hline & (zeer) tevreden & 54 & 51 \\
\hline \multirow[t]{3}{*}{ Tevredenheid: Begeleiding vanuit werk } & (zeer) ontevreden & 10 & 9 \\
\hline & neutraal & 20 & 17 \\
\hline & (zeer) tevreden & 71 & 74 \\
\hline
\end{tabular}




\section{Fact Sheet}

ROA-F-2018/17

Bijlage 3: Resultaten per opleidingsniveau

\begin{tabular}{|c|c|c|c|c|c|}
\hline & & Niveau 1 & Niveau 2 & Niveau 3 & Niveau 4 \\
\hline \multicolumn{6}{|l|}{ Westerse migratieachtergond } \\
\hline \multirow[t]{4}{*}{ Aantal keren solliciteren } & 1 tot 3 & 84 & 80 & 86 & 83 \\
\hline & 4 tot 6 & 6 & 9 & 6 & 8 \\
\hline & 7 tot 10 & 2 & 4 & 3 & 3 \\
\hline & meer dan 10 & 8 & 6 & 5 & 6 \\
\hline \multirow[t]{2}{*}{ Problemen ondervonden bij vinden van stage/bpv-plaats } & $\mathrm{Ja}$ & 20 & 20 & 18 & 21 \\
\hline & Nee & 80 & 80 & 82 & 79 \\
\hline \multirow[t]{2}{*}{ Alle aspecten van het beroep aan bod gekomen } & $\mathrm{Ja}$ & 68 & 78 & 81 & 79 \\
\hline & Nee & 32 & 22 & 20 & 21 \\
\hline \multirow[t]{3}{*}{ Tevredenheid: Begeleiding vanuit school } & (zeer) ontevreden & 11 & 17 & 22 & 23 \\
\hline & neutraal & 24 & 25 & 25 & 26 \\
\hline & (zeer) tevreden & 64 & 58 & 53 & 51 \\
\hline \multirow[t]{3}{*}{ Tevredenheid: Begeleiding vanuit werk } & (zeer) ontevreden & 10 & 13 & 11 & 10 \\
\hline & neutraal & 23 & 20 & 20 & 19 \\
\hline & (zeer) tevreden & 67 & 68 & 70 & 71 \\
\hline \multicolumn{6}{|l|}{ Niet-westerse migratieachtergond } \\
\hline \multirow[t]{4}{*}{ Aantal keren solliciteren } & 1 tot 3 & 78 & 73 & 71 & 70 \\
\hline & 4 tot 6 & 11 & 13 & 11 & 12 \\
\hline & 7 tot 10 & 3 & 4 & 6 & 6 \\
\hline & meer dan 10 & 8 & 11 & 12 & 12 \\
\hline \multirow[t]{2}{*}{ Problemen ondervonden bij vinden van stage/bpv-plaats } & Ja & 24 & 24 & 26 & 24 \\
\hline & Nee & 76 & 76 & 74 & 76 \\
\hline \multirow[t]{2}{*}{ Alle aspecten van het beroep aan bod gekomen } & Ja & 71 & 76 & 79 & 77 \\
\hline & Nee & 29 & 24 & 21 & 23 \\
\hline \multirow[t]{3}{*}{ Tevredenheid: Begeleiding vanuit school } & (zeer) ontevreden & 8 & 16 & 20 & 21 \\
\hline & neutraal & 18 & 23 & 25 & 25 \\
\hline & (zeer) tevreden & 74 & 61 & 55 & 54 \\
\hline \multirow[t]{3}{*}{ Tevredenheid: Begeleiding vanuit werk } & (zeer) ontevreden & 10 & 12 & 12 & 11 \\
\hline & neutraal & 18 & 21 & 20 & 20 \\
\hline & (zeer) tevreden & 72 & 68 & 67 & 69 \\
\hline \multicolumn{6}{|l|}{ Zonder migratieachtergrond } \\
\hline \multirow[t]{4}{*}{ Aantal keren solliciteren } & 1 tot 3 & 85 & 87 & 89 & 87 \\
\hline & 4 tot 6 & 7 & 7 & 6 & 7 \\
\hline & 7 tot 10 & 2 & 2 & 2 & 3 \\
\hline & meer dan 10 & 6 & 5 & 3 & 4 \\
\hline \multirow[t]{2}{*}{ Problemen ondervonden bij vinden van stage/bpv-plaats } & Ja & 17 & 17 & 14 & 16 \\
\hline & Nee & 83 & 83 & 86 & 84 \\
\hline \multicolumn{6}{|l|}{ Alle aspecten van het beroep aan bod gekomen } \\
\hline & Ja & 73 & 83 & 86 & 85 \\
\hline & Nee & 27 & 17 & 14 & 15 \\
\hline \multicolumn{6}{|l|}{ Tevredenheid: Begeleiding vanuit school } \\
\hline & (zeer) ontevreden & 16 & 21 & 21 & 23 \\
\hline & neutraal & 23 & 27 & 28 & 26 \\
\hline & (zeer) tevreden & 62 & 52 & 51 & 51 \\
\hline \multicolumn{6}{|l|}{ Tevredenheid: Begeleiding vanuit werk } \\
\hline & (zeer) ontevreden & 12 & 10 & 9 & 8 \\
\hline & neutraal & 21 & 20 & 18 & 16 \\
\hline & (zeer) tevreden & 67 & 69 & 73 & 76 \\
\hline
\end{tabular}




\section{MBO Stages en de migratieachtergrond van studenten}

Bijlage 4: Resultaten per opleidingssector

\begin{tabular}{|c|c|c|c|c|c|c|}
\hline & & Landbouw & Techniek & Economie & $\begin{array}{r}\text { Gezondheids- } \\
\text { zorg }\end{array}$ & $\begin{array}{r}\text { Gedrag \& } \\
\text { Maatschappij }\end{array}$ \\
\hline \multicolumn{7}{|l|}{ Westerse migratieachtergond } \\
\hline \multirow[t]{4}{*}{ Aantal keren solliciteren } & 1 tot 3 & 82 & 84 & 80 & 87 & 91 \\
\hline & 4 tot 6 & 7 & 6 & 10 & 7 & 5 \\
\hline & 7 tot 10 & 2 & 4 & 4 & 2 & 1 \\
\hline & meer dan 10 & 9 & 6 & 7 & 4 & 3 \\
\hline \multirow[t]{2}{*}{ Problemen ondervonden bij vinden van stage/bpv-plaats } & $\mathrm{Ja}$ & 18 & 17 & 23 & 19 & 12 \\
\hline & Nee & 82 & 83 & 77 & 81 & 88 \\
\hline \multirow[t]{2}{*}{ Alle aspecten van het beroep aan bod gekomen } & $\mathrm{Ja}$ & 75 & 79 & 74 & 83 & 83 \\
\hline & Nee & 25 & 21 & 26 & 17 & 17 \\
\hline \multirow[t]{3}{*}{ Tevredenheid: Begeleiding vanuit school } & (zeer) ontevreden & 26 & 23 & 19 & 19 & 18 \\
\hline & neutraal & 26 & 24 & 25 & 26 & 26 \\
\hline & (zeer) tevreden & 48 & 53 & 56 & 55 & 57 \\
\hline \multirow[t]{3}{*}{ Tevredenheid: Begeleiding vanuit werk } & (zeer) ontevreden & 8 & 11 & 11 & 14 & 5 \\
\hline & neutraal & 19 & 22 & 19 & 20 & 16 \\
\hline & (zeer) tevreden & 73 & 68 & 70 & 66 & 79 \\
\hline \multicolumn{7}{|l|}{ Niet-westerse migratieachtergond } \\
\hline \multirow[t]{4}{*}{ Aantal keren solliciteren } & 1 tot 3 & 84 & 74 & 65 & 83 & 79 \\
\hline & 4 tot 6 & 8 & 10 & 14 & 8 & 10 \\
\hline & 7 tot 10 & 4 & 5 & 6 & 3 & 4 \\
\hline & meer dan 10 & 4 & 11 & 15 & 6 & 7 \\
\hline \multirow[t]{2}{*}{ Moeite ondervonden bij vinden van stage/bpv-plaats } & $\mathrm{Ja}$ & 15 & 24 & 27 & 20 & 22 \\
\hline & Nee & 85 & 76 & 73 & 80 & 78 \\
\hline \multirow[t]{2}{*}{ Alle aspecten van het beroep aan bod gekomen } & $\mathrm{Ja}$ & 68 & 76 & 74 & 81 & 83 \\
\hline & Nee & 32 & 24 & 27 & 19 & 17 \\
\hline \multirow[t]{3}{*}{ Tevredenheid: Begeleiding vanuit school } & (zeer) ontevreden & 9 & 19 & 18 & 15 & 17 \\
\hline & neutraal & 25 & 26 & 24 & 20 & 22 \\
\hline & (zeer) tevreden & 66 & 56 & 57 & 65 & 61 \\
\hline \multirow[t]{3}{*}{ Tevredenheid: Begeleiding vanuit werk } & (zeer) ontevreden & 6 & 12 & 12 & 11 & 8 \\
\hline & neutraal & 22 & 23 & 20 & 19 & \\
\hline & (zeer) tevreden & 72 & 65 & 68 & 70 & 74 \\
\hline \multicolumn{7}{|l|}{ Zonder migratieachtergrond } \\
\hline \multirow[t]{4}{*}{ Aantal keren solliciteren } & 1 tot 3 & 85 & 87 & 85 & 90 & 91 \\
\hline & 4 tot 6 & 9 & 7 & 8 & 5 & 5 \\
\hline & 7 tot 10 & 3 & 2 & 3 & 2 & 2 \\
\hline & meer dan 10 & 4 & 4 & 5 & 3 & 3 \\
\hline \multirow[t]{2}{*}{ Moeite ondervonden bij vinden van stage/bpv-plaats } & $\mathrm{Ja}$ & 18 & 16 & 16 & 14 & 14 \\
\hline & Nee & 82 & 84 & 84 & 86 & 86 \\
\hline \multirow[t]{2}{*}{ Alle aspecten van het beroep aan bod gekomen } & Ja & 85 & 85 & 82 & 87 & 88 \\
\hline & Nee & 15 & 16 & 18 & 14 & 12 \\
\hline \multirow[t]{3}{*}{ Tevredenheid: Begeleiding vanuit school } & (zeer) ontevreden & 25 & 23 & 22 & 19 & 19 \\
\hline & neutraal & 29 & 29 & 26 & 25 & 25 \\
\hline & (zeer) tevreden & 46 & 48 & 52 & 56 & 55 \\
\hline \multirow[t]{3}{*}{ Tevredenheid: Begeleiding vanuit werk } & (zeer) ontevreden & 7 & 9 & 10 & 9 & 6 \\
\hline & neutraal & 19 & 19 & 18 & 17 & 14 \\
\hline & (zeer) tevreden & 74 & 72 & 72 & 74 & 79 \\
\hline
\end{tabular}




\section{Colofon}

(๑) Researchcentrum voor Onderwijs en Arbeidsmarkt Niets uit deze uitgave mag op enige manier worden verveelvoudigd zonder voorafgaande schriftelijke toestemming van de directeur van het ROA.

Researchcentrum voor Onderwijs en Arbeidsmarkt

Maastricht University

School of Business and Economics

secretary-roa-sbe@maastrichtuniversity.nl

www.roa.nl

Deze factsheet is uitgebracht in opdracht van het Ministerie van OCW

\section{Vormgeving}

ROA secretariaat, Maastricht

september 2018 